Article

\title{
The Ministering Critic: Kierkegaard's Theology of Communication
}

\author{
Russell Johnson $(\mathbb{D}$ \\ Divinity School, University of Chicago, Chicago, IL 60637, USA; rpjohnson@uchicago.edu
}

Received: 5 December 2019; Accepted: 2 January 2020; Published: 8 January 2020

\begin{abstract}
This paper analyzes Kierkegaard's scattered writings on communication to foreground the distinctively theological dimension of Kierkegaard's rhetorical theory. "Indirect communication" needs to be understood as a strategy to address a specific theological problem, namely, the tendency for readers who think they are already Christian to dismiss or domesticate rhetoric that summons them to authentic Christian existence. Since Christianity is an "existence-communication," the questions of what it means to be a Christian and how one can faithfully communicate Christianity are integrally linked for Kierkegaard. Contemporary apologists, activists, and preachers who rely on more direct modes of communication to express the Christian gospel have much to learn from Kierkegaard's grappling with the illusions that beset Christian witness.
\end{abstract}

Keywords: Kierkegaard; rhetoric; faith; illusions; theology; indirect communication

"A new science must be introduced," Kierkegaard writes, "The Christian art of speaking, to be constructed admodum Aristotle's Rhetoric." (Kierkegaard 1999). Though Kierkegaard never completed a treatise on Christian communication, his writings reveal a sustained reflection on the dangers that beset efforts to proclaim the Christian gospel. His later writings form arguably the most profound and innovative Christian theology of communication since Augustine. ${ }^{1}$ In this paper, I discuss some of Kierkegaard's contributions to the developing field of "rhetorical theology" (Compier 1999) and propose an approach to preaching, activism, and apologetics that takes seriously the effect illusions have on a person's capacity to encounter authentic Christianity.

In this article, I will explicate several ideas Kierkegaard develops late in his career, primarily in the works collected in The Point of View and corresponding entries in the Journals and Papers. ${ }^{2}$ In these works, Kierkegaard offers an interpretation of his earlier writings, insisting that his stylistic choices were part of a sustained effort to overcome the illusions that prevent people from encountering the offensive, life-giving message of Jesus. Scholars dispute whether or not the later Kierkegaard should be believed on this point, and it is not my intention here to weigh in on this debate. ${ }^{3}$ Whether or not

1 See especially (Augustine 1997). Just as Kierkegaard's theology has been underappreciated, so too have his contributions to rhetorical theory. Walter Jost wrote in 1994 that Kierkegaard is "simply missing from all of the standard accounts of rhetoric and its history." Jost goes on to theorize why this is the case and works to correct this oversight. (Jost 1994). Since then, a notable exception to this trend is the work of John Durham Peters. Peters notes that "Kierkegaard is perhaps the first to make communication per se a philosophical problem," and writes (insightfully, I think) that "in a broad sense, communication is the theme of all of his works." (Peters 2012).

2 Since my focus is chiefly on indirect communication, I will refrain from discussing Kierkegaard's "Attack on Christendom" toward the end of his life, which was more direct (though Kierkegaard maintained it still had an element of indirectness).

3 Interpreters dispute whether to take Kierkegaard's reflections on his own authorship as faithful representations of his earlier motives, as a further layer of irony meant to illustrate the inadequacy of language, or as an all-too-tidy post hoc reinterpretation of a more complicated history. As Joakim Garff rightly notes, with The Point of View "Kierkegaard founded Kierkegaard research," and his self-interpretation is not infallible (See Garff 2005). For a recent survey of the debate, see (Roberts 2019). 
the later Kierkegaard's interpretation is an accurate account of the early Kierkegaard's motives, these later writings are valuable in their own right as contributions to "the Christian art of speaking."

Kierkegaard's reflections are compelling because they are not merely general rhetorical principles applied to Christian proclamation, but the centerpiece of a full-fledged rhetorical theology. Kierkegaard connects the content of Christian message with the forms by which it gets communicated. ${ }^{4}$ In proclaiming Christianity incorrectly, he argues, preachers and theologians can unwittingly transform the Christian message into something it is not-a philosophical theory, a hollow identity marker, one side in a culture war, or a pretense for judging others. Even though contemporary Christians may face different illusions than those Kierkegaard wrestled with, this problem still threatens Christian communication, and we have much to learn from this strand of Kierkegaard's thought.

Kierkegaard's central task as a writer, as he understood it in his later years, was to diagnose how Christianity was misrepresented in his time and then write in a way that could serve as a corrective to these misunderstandings. (Kierkegaard 1998a). Motivated by the insight that "by a direct attack [the critic] only strengthens a person in the illusion," (Kierkegaard 1998a) he develops an approach to communication that is indirect-subverting, redirecting, and out-narrating his interlocutors' misguided viewpoints. This approach is informed by an assessment of the beliefs and assumptions of his interlocutors, attention to the dynamics of assent, and —most importantly—a nuanced understanding of Christian faith.

We often assume that, in the effort to overcome a false view, the most effective approach is direct, forceful opposition. Resisting a false viewpoint is like winning a game of tug-of-war; we need to yield no ground and pull the opponent toward our position. In order for our side to win in a struggle between truth and falsehood, we need more powerful arguments, more passionate rhetoric, and unwavering conviction if we want the truth to win out.

Though Christian apologists, activists, and preachers often operate under this assumption, Kierkegaard offers reason to believe that the direct, oppositional approach is not necessarily the best one, especially when it comes to expressing an authentically Christian message. Resistance of this sort may be rendered inert, may ironically drive interlocutors deeper into their illusions, or may capture speakers in these same illusions. Efforts to end conflicts often ironically exacerbate those conflicts, and similarly the efforts to overcome illusions may often ironically confirm those illusions in the minds of the interlocutors. A different approach is needed-a "new science" - to free all parties from these entrenched illusions and clear the path for truth.

\section{The Illusions of Christendom}

Living in the heavily Lutheran city of Copenhagen in the nineteenth century, Kierkegaard was surrounded by preachers expounding Christian teachings, philosophers demonstrating the truth of Christian precepts, and public rituals of Christian adherence. In Christendom (that is, a setting where it is assumed that almost everyone is Christian), explicitly theological speech was in no short supply. However, Kierkegaard maintained that the true message of Christianity was being distorted, or as he said, "abolished, if in no other way, then by the wrong, unchristian form that is given to the Christian communication." 5

What is an unchristian form of communication? For Kierkegaard, an essential part of the Christian life is self-examination and imitation, finding oneself confronted by Christ and beckoned to follow. The grammar of Christianity, what Christianity is, is not a set of objective statements about God and the

4 For the purposes of this article, I will focus on The Point of View and the Journals and Papers and the interpretation they give of the pseudonymous writings more so than the earlier writings themselves. As Paul Holmer reminds us, even if we disbelieve Kierkegaard that the pseudonymous writings are religious works communicated indirectly, the theory of indirect communication is still worthwhile. (Holmer 2012b). I will draw attention to a pseudonym only when the passage referred to seems at odds with what Kierkegaard writes under his own name.

5 The Point of View, 122. 
world but a transforming relationship with God and a repentant way of living in light of revealed truth. If one communicates Christianity in a way that makes it seem objective, making it seem like a system of ideas that one can evaluate disinterestedly and impersonally, then, according to Kierkegaard, that person has communicated something other than Christianity without realizing it. Hearing the gospel is closer to hearing an order, an accusation, or an invitation than it is to hearing a hypothesis. Thus the means of rationalistic apologetics, moralistic preaching, and idealistic theology lead to the ends of superficial conversion or superficial rejection, or of belief in something less than or other than Christianity, not to actual engagement with the demanding message of Christ. In Kierkegaard's terms, these forms of communication keep Christianity in the sphere of the speculative, without affecting the existing person.

An analogy is instructive. ${ }^{6}$ Say a pastor tells his congregation that it is wrong to gossip. The parishioners all nod knowingly, but then go home and continue gossiping unabated, while nonetheless assenting to the proposition that it is wrong to gossip. Kierkegaard insists that this happens because people are under the illusion that they are not gossips, or that what they do is harmless. Kierkegaard says of instances such as this that both the communication and the reception are purely external to the audience, matters of objective, abstract belief. The message gets stored in the repository of moral facts, to be dragged out only when deemed necessary. Even if the pastor tells his congregation that one should not merely believe gossip is wrong, but that they should apply this to their own lives, the congregation will still nod knowingly and agree that one should indeed apply this moral lesson to one's life, and then go home and continue gossiping all the same. By telling people who already think gossip is wrong that gossip is wrong, you offer them only the opportunity to reassure themselves that they are moral people because they hold proper moral beliefs. Moral exhortation, when the audience is under such an illusion, leads more to self-righteousness than to repentance and reform.

The principal illusions Kierkegaard contends with are those of Christendom. ${ }^{7}$ He writes:

In the communication of Christianity, when the situation is Christendom, there is not a direct relation, there is first of all a delusion to remove. The entire old science of arms, all the apologetics and everything belonging to it, serves instead, to put it bluntly, to betray the cause of Christianity. At every point and at every moment, the strategy must be constituted on the basis of having to contend with a delusion, an illusion. ${ }^{8}$

To understand what Kierkegaard is saying in this passage, we need to attend to his description of the illusions of Christendom. In Kierkegaard's time, to be Danish was to be Lutheran, so "thousands and thousands, as a matter of course, call themselves Christian." ${ }^{\prime 9}$ The majority in Christendom consider themselves Christian, "But there is no ear for what Christianity requires regarding self-denial, renunciation, and seeking first the Kingdom of God." ${ }^{10}$ According to Kierkegaard, these people are not lying so much as they are self-deceived; they have lost sight of what Christianity truly means and hold on to it as a hollow identity marker. In the so-called Christian nation of Denmark, "Christianity" becomes a matter of church membership, doctrinal confessions, and culturally-sanctioned rituals. What is truly essential to Christianity, relating one's whole self to the triune God, is absent. This absence is obscured by sermons that reinforce the idea that Christianity makes no demands on one's life beyond the demands of good Danish citizenship. Hence, when he talks about Christendom, Kierkegaard

\footnotetext{
Cf. (Kierkegaard 1992, 1997).

Kierkegaard treats Christendom as a single illusion, but for the purposes of explicating his meaning, I treat it as a cluster of related illusions.

8 Kierkegaard, The Point of View, 52f. Kierkegaard makes several references to "betrayal" in communication. See Point of View, 80, 280; Christian Discourses, 162, 190; (Kierkegaard 1980, 1991); Concluding Unscientific Postscript, 49.

9 The Point of View, 41. The idea of "Christendom" often has a political dimension, and this is true for Kierkegaard as well, but I will not discuss it here.

10 Journals and Papers, 1:383; cf. 1:397, "It is the other and really decisive side of Christianity which has been abolished in Christendom. Christianity has become a doctrine; but conversion, rebirth, imitation, dying away from this world, renunciation, self-denial, etc.- - they are as if blown away."
} 
means "the illusion that in such a country all are Christians,"11 a universality obtained at the cost of "Christianity" meaning nothing at all.

On Kierkegaard's analysis, Danish culture includes at least three illusions that hinder people from recognizing authentic Christianity. As we will discuss in greater detail later, Kierkegaard maintains that Christian communication betrays the gospel to the extent that it feeds into these illusions rather than subverting them.

First, there is the illusion that what it means to be a Christian can be deduced from the behavior of other self-identified Christians. Consider this: the way I determine whether or not I am tall is by looking around at the people in my society and estimating the average height, then comparing myself to that average. In practice, what it means to be tall is determined by comparison with others in one's society. In Christendom, the label "Christian" gets treated this way, and Kierkegaard insists that actual Christianity is abolished in the process.

For Kierkegaard, Christianity is a matter of the single individual's unique relation to Christ. One determines whether one is a Christian not by comparing oneself to others, but by comparing oneself to Christ. ${ }^{12}$ One is a Christian not by virtue of one's membership in good standing of a church, but by one's utter reliance upon God's grace. If you ask someone whether they are Christian, and they say yes based on their church attendance, baptism, similarity to other Christians, and difference from non-Christians, then they have not simply overestimated their piety but have misunderstood the question. If they really understood the question, they would look to Christ, recognize their own sins and failings, and trust that God will forgive them, sustain them, and command them to love.

Kierkegaard's goal is not to make people more passionately Christian or present a more demanding version of Christian life. To make Christianity quantitatively more demanding only contributes to the illusion; the goal is not to make the standard higher but to make the standard Christ. This is categorically different. Kierkegaard wants to make people recognize that they have misconstrued the gospel and turned Christianity into something it is not. He makes this point throughout his writings using the language of "the crowd" and "the single individual." His aim is not to disparage communities or promote individualism, as is sometimes thought, but "with expert one-sidedness"13 to challenge this illusion and present the question of Christianity correctly.

A second illusion prevalent in Christendom is the assumption that Christianity is principally a matter of believing doctrines. Kierkegaard writes that in Christendom:

Christianity is regarded as a sum of doctrines; lectures are given on it in the same way as on ancient philosophy, Hebrew, or any branch of knowledge whatever, with the listener or the learner's relation to it left as a matter of indifference. Basically this is paganism. The essentially Christian is precisely this: the relation to Christianity is what is decisive. Someone can know all about Christianity, can know how to explain, discuss, expound-but if in addition he thinks that his own personal relation to Christianity is a matter of indifference, then he is a pagan. But, just as all regimes have been overthrown, so also has Christianity been overthrown. Rather than it should rule over people, transform their lives, not only on Sunday but every day, intervene decisively in all relationships of life, it is kept at a scholarly distance as mere doctrine, the agreement between its various doctrines is shown-but your life and my life, the agreement or nonagreement in the lives of people with this doctrine-that is a matter of indifference. ${ }^{14}$

11 The Point of View, 23.

Kierkegaard, For Self-Examination, 200.

3 The Point of View, 205.

14 Søren Kierkegaard, Christian Discourses, 214-15. Cf. For Self-Examination, 39, 127-42; Concluding Unscientific Postscript, 326-31, 379-80, 570; Point of View, 129-30; Journals and Papers, 1:401. 
The problem is not that people have stopped believing in Christianity, nor that they have been insufficiently pious, but that they have come to treat Christianity as a set of ideas that could be evaluated at arm's length. On this reckoning, a person is a Christian so long as they intellectually assent to the objective truth of Christian doctrines. Even if Kierkegaard's contemporaries might not explicitly agree with this assessment, Kierkegaard recognizes his assumption is embedded in how words like "faith" and "belief" are typically used. ${ }^{15}$

Kierkegaard contrasts doctrines with what he calls "existence." Intellectual assent to a set of propositions is not sufficient for faith; one needs to understand Christian truths in relation to oneself. It is not enough to believe them; one must understand one's life in light of them and act accordingly. Paul Holmer summarizes Kierkegaard's point well: "All the doctrines of Christian history together do not add up to the knowledge of God, any more than does general psychology add up to self-knowledge." (Holmer 2012a).

Kierkegaard believes that his culture is under the illusion that theological belief is prior to and more important than existential commitment. "In Kierkegaard's view," Stephen Toulmin and Allan Janik write, "the greatest disaster that ever befell Christianity was the attempt to express its truths in speculative terms. As a result, Christianity contradicted itself. Speculative truth is a matter of universal and complete knowledge, true for all time; whereas Christianity has to do with the existing person, who is always in a state of becoming, always an individual. Speculation is concerned with 'objective truth,' Christianity is rooted in subjective truth, a notion which lies close to the heart of all Kierkegaard's thinking." (Toulmin and Janik 1973). Kierkegaard's point is difficult to pin down for a variety of reasons, but in short he argues that Christianity is not a position that one first acknowledges the truth of and then, in a separate act, relates to one's own life. Consider the difference between someone saying to you, "I love all people" and someone saying to you, "I love you." Logically speaking, the second one is entailed by the first. But the second is costlier, more profound, and more personal. It has a dimension of meaning — which Kierkegaard calls the pro me [for me]-that the first lacks. ${ }^{16}$ When Kierkegaard writes that "Christianity is not a doctrine," 17 his point is that you do not understand the Christian gospel unless you understand it as addressed to you, as involving you.

We can make a distinction between thinking Christianity is true in a generic way (that God created all people, all have sinned, Christ died for all people, etc.) and thinking Christianity is true in an individuated way (that God created me, that I have sinned, that Christ died for me, etc.). It is common for theologians and apologists to deal primarily with Christianity as a set of generic truths - doctrines—and to be indifferent about how people individuate these truths or to assume that people will individuate these truths privately as a matter of course. Kierkegaard, by contrast, maintained that the gospel is always individuated, and to treat it as something generic, even for a moment, is to be under an illusion. This illusion is especially pernicious because the notion that one should not simply assent to something, but should apply it to one's life, is itself a notion that can be treated as something objective, as a principle to be assented to without applying it to one's life.

A person can intellectually assent to a proposition without that assent influencing their actions. When this happens, people become self-deceived. They think they hold to principles and will agree with those principles when they hear them propounded, all the while the principles are not governing their actions. Hence, when Kierkegaard says people are under an illusion, he does not mean that they intellectually assent to false beliefs, but that the way they live their lives is in some sense false-either because it does not correspond to reality (including the reality of God's redeeming grace) or because it does not correspond to their own expressed commitments.

15 "I understand it as my task to extricate the Christian concepts from the illusions in which we have entangled them, and in so doing work toward an awakening." Journals and Papers, 6:554; cf. 1:390. Cf. (Kierkegaard 1995).

16 The pro me is a central theme in Christian Discourses and For Self-Examination. On the pro me in Philosophical Fragments and Concluding Unscientific Postscript, see (Aumann 2008).

17 Concluding Unscientific Postscript, 379, 570. Cf. For Self-Examination 127-131; Point of View, 129; Christian Discourses, $214-215$. 
A third illusion of Christendom in nineteenth-century Denmark is the one-dimensional emphasis on grace. Lutheranism emphasizes salvation by grace through faith independent of one's works. This notion was revolutionary in Luther's Germany, but had become mundane in Kierkegaard's Denmark. As Kierkegaard writes:

Now there will again be an uproar claiming that I proclaim only the law, urge imitation [of Christ] too strongly, and the like ... And they will say: We cannot stop with this; we must go further-to grace, where there is peace and rest. You babble nonsense. For the average person, Christianity has shriveled to sheer meaninglessness, a burlesque edition of the doctrine of grace, that if one is Christian one lets things go their way and counts on God's grace. But because everything that is essentially Christian has shriveled to meaninglessness this way, they are unable to recognize it again when pathos-filled aspects are delineated. They have the whole thing in an infinitely empty, abstract summary-and thus think they have gone further than the successive unfolding of the pathos-filled aspects. Nothing can be taken in vain as easily as grace; as soon as imitation is completely omitted, grace is taken in vain. But that is the kind of preaching people like. ${ }^{18}$

As this passage suggests, for Kierkegaard, the significance of an idea or event sometimes depends upon its placement within a sequence. Significance is inherently dramatic; unless one takes the time to dwell on what comes before, one will not be able to fully appreciate what comes after. This is the case whether one is solving puzzles, reading novels, or watching sporting events—all of these are in some sense building toward a conclusion, but if one rushes impatiently to the conclusion one will not be able to appreciate its significance. Only when we reckon with the demand-to imitate Christ-and with our own inability to live up to this demand-sin-can we recognize the gift of grace for what it truly is. Outside of this context of absolute demand and absolute failure, the idea of salvation by grace becomes something else, a "burlesque."

In Kierkegaard's soteriology, there are four "stages" or "spheres"19 of the Christian life: (1) the demand, God expects something of every person, (2) the fall, the person cannot live up to the demand, (3) the gift, God offers grace and forgiveness to sinners, and (4) "existence-communication,"20 the person lives into God's declaration of who they are, and witnesses through their words and actions to the good news. While there is an order to these four, to call them "stages" might be misleading, because one does not move beyond the lower stages as one moves into the higher. The Christian is, in Luther's phrase, simul justus et peccator, simultaneously redeemed and a sinner. Likewise, someone who is in the fourth stage always remains in the other three-always called upon to be perfect, always in the wrong, always dependent upon the grace of God.

As Kierkegaard sees it, the massive illusion of Christendom is that Christians think they have already passed through stages one through three, and that since they have completed these stages, nothing more is needed. Salvation is seen as something accomplished, as a "result," a fait accompli. Being a Christian is like being an Eagle Scout, a PhD, or an Olympic medalist-it means one has done something in the past (or had something done for one in the past), and it carries no real demands save a few cultural expectations for how one is to act in the present. People under this illusion still use the language of law, sin, and grace, but these concepts are "meaningless" because they are matters of the past, stages one has

18 The Point of View, 248. Cf. 16; Journals and Papers, 1:389, 1:401, 1:763; For Self-Examination, 150-213.

19 On Kierkegaard's use of "stages" and "spheres," see (Tietjen 2013). These are different from the esthetic, the ethical, and the religious "stages" Kierkegaard addresses throughout his work.

20 Concluding Unscientific Postscript, 380, 560, 570, 608. A key element of becoming Christian for Kierkegaard, which for the sake of space I do not address here, is self-denial and suffering. He writes, "If Christianity is to be reintroduced into Christendom, it must again be proclaimed unconditionally as imitation, as law, so Christianity does not become the conjunctive (which sanctifies all our cherished relationships and our earthly fortune and striving) but the disjunctive: to let go of everything, to hate one's father and mother and oneself." Journals and Papers, 1:401. 
moved beyond. Under this illusion, all that is required of the Christian in the present is an occasional expression of gratitude to God and to remember God's pardon whenever they feel guilty.

In Kierkegaard's theology, however, the Christian life is always dynamic and unfolding. Kierkegaard emphasized the need to "work out your own salvation with fear and trembling." 21 The fourth stage-existence-communication-is the way of life Christians are called to, and it is characterized by becoming and witnessing. Kierkegaard reiterates that it is very difficult for someone to communicate the necessity of this fourth stage to those under the illusion. As the passage quoted above says, "They have the whole thing in an infinitely empty, abstract summary-and thus think they have gone further than the successive unfolding of the pathos-filled aspects." If one proclaims existence-communication and one's message sounds like the demand or the fall, then people will promptly fill in the ending of the story by moving along to the gift. In response to a spur to Christian action, they will emphasize grace in a way that neutralizes the challenge. This is an example of what Kierkegaard calls "sagacity," 22 the sense (often mistaken) that one already knows the ending and so does not need to learn anything new or do anything more. A sagacious audience is difficult to communicate to, since, as Kierkegaard writes, "To presume to communicate the truth directly to one who is untruth, who believes falsehood, will likely be met with resistance, rejection, dismissal-for, from the perspective of the other, one is presuming to give them something they already have, something they do not lack, namely the truth."23

To summarize, for Kierkegaard, the Christian gospel demands to be communicated in ways that take into consideration how audiences will likely receive it. To do otherwise is not simply to communicate the gospel poorly, but to "betray" the gospel by misleading one's audience about what it is to be a Christian. When one's audience is under the illusions of Christendom, activism and apologetics for Christianity can often subtly transform the Christian gospel into something other than what it truly is.

In this section, I have surveyed three interrelated illusions Kierkegaard diagnosed in his situation. First, the illusion that people are Christian as a matter of course, and that you learn what it means to be Christian by comparing yourself with the crowd. ${ }^{24}$ Second, the illusion that Christianity is a set of doctrines to assent to, a set of objective truths one can believe without self-examination and transformation. Third, the illusion that the essentially Christian is something Christians already know, perhaps have known since childhood, and that to be a Christian is to have undergone something in the past that has only a minimal bearing on one's present existence.

The difficulty of disabusing someone of an illusion is that the illusion makes it difficult for them to realize they are under an illusion. For those under an illusion, the illusion also colors any attempts at removing it. To "introduce Christianity—into Christendom," 25 necessarily involves precision, lest one betray one's goals by confirming these illusions in the minds of his audience. ${ }^{26}$ If, for example, one makes one's description of Christianity sound like yet another idea one can assent to without self-examination, then to some degree one has not faithfully represented Christianity. ${ }^{27}$ To navigate through this rhetorical mine field, Kierkegaard developed a theory of indirect communication, to which we will now turn.

\footnotetext{
Philippians 2:12 (KJV).

The Point of View, 163

Simpson, The Truth Is the Way, 12.

Evans, Kierkegaard's Fragments and Postscript, 52.

Kierkegaard, Journals and Papers, 1:388.

The Point of View, 125.

27 Kierkegaard sees his task as necessarily both positive and negative. Cf. Concluding Unscientific Postscript, 85, 275; The Point of View, 88, 235; Journals and Papers 1:760. Cf. Evans, Kierkegaard's Fragments and Postscript, 105.
} 


\section{Faithful Communication}

Kierkegaard writes, "The situation (becoming a Christian in Christendom, where consequently one is a Christian) ... makes an indirect method necessary, because the end task here must be to take measures against the illusion: calling oneself a Christian, perhaps deluding oneself into thinking one is that without being that ... In relation to pure receptivity, like the empty jar that is to be filled, direct communication is appropriate, but when the illusion is involved, consequently something that must first be removed, direct communication is inappropriate. ${ }^{28}$ But what does he mean by "direct communication" and why is it inappropriate for this task? What rhetorical approaches are appropriate to the task of removing illusions and facilitating commitment to the Christianity of the New Testament? Addressing these questions is our task for the rest of this article. For Kierkegaard, faithful communication of Christianity in the context of Danish Christendom demands a distinctive way of thinking about one's message, one's audience, one's communicative style, and oneself. I will analyze four of his ideas that have particular relevance for Christian proclamation today.

\section{Not Antagonizing, but Ministering}

Though Kierkegaard does not offer a definition of "direct communication," the term seems to include straightforward statements of one's views, arguments in favor of one's position, declamations and proclamations, polemic and didactic communication, and explicit attempts to convince others. Kierkegaard believed that when one's audience is under an illusion, a direct attack on the illusion will not be effective. "No," he writes, "an illusion can never be removed directly, and basically only indirectly." ${ }^{29}$ He continues:

Every once in a while a religious enthusiast appears. He makes an assault on Christendom; he makes a big noise, denounces nearly all as not being Christians-and he accomplishes nothing. He does not take into account that an illusion is not so easy to remove. If it is the case that most people are under an illusion when they call themselves Christians, what do they do about an enthusiast like that? First and foremost, they pay no attention to him at all, do not read his book but promptly lay it ad acta [aside]; or if he makes use of the Living Word, they go around on another street and do not listen to him at all. Then by means of a definition they smuggle him outside and settle down quite securely in their illusion. They make him out to be a fanatic and his Christianity to be an exaggeration - in the end he becomes the only one, or one of the few, who is not a Christian in earnest (since exaggeration, after all, is a lack of earnestness); the others are all earnest Christians. ${ }^{30}$

People under an illusion have psychological countermeasures at the ready that might activate when they sense their views or lifestyles are under attack.

First, people will tend to disregard someone whose viewpoint is utterly at odds with their own. To the extent that one sees oneself as reasonable and informed, one will be likely to dismiss positions at odds with one's own as unreasonable or uninformed unless the one asserting the position is especially credible. ${ }^{31}$ Since people in Christendom think they already know what it means to be a Christian, anyone who says otherwise will likely be dismissed as unreasonable.

Second, since people in Christendom rely on "the crowd" to determine what it means to be a Christian, anyone who preaches a different version of Christianity will likely be framed as an outsider.

28 The Point of View, 8. Even though Kierkegaard reiterates that the Christian gospel is "direct-indirect," for the sake of space I will focus primarily on the indirect task of communicating the gospel in Christendom. For a helpful review of the different scholarly interpretations of Kierkegaard's writings on indirect communication, see Aumann, "Kierkegaard and the Need for Indirect Communication."

29 The Point of View, 43.

30 The Point of View, 42-43; cf. 132-133. Cf. Concluding Unscientific Postscript, 566-569; Journals and Papers, 1:639.

31 For example, since I believe that climate change is real, I will not pay any heed to an online article that claims otherwise, unless it is published in a well-regarded science journal or written by a climate scientist at a reputable university. 
Audiences will categorize the critic in a way that renders their claims not binding on the majority. This is what Kierkegaard means when he writes, "by means of a definition they smuggle him outside." This dismissal-by-categorization can take several forms. The critic can be lumped into a negative category—a fanatic, an extremist, a bigot—and summarily disregarded ${ }^{32}$ Alternately, the critic can be treated as a product of another community, whose criticisms are treated as informative about the attitudes of that community more so than truth-claims about one's own community. ${ }^{33}$ The critic could also be dismissed by being placed on a pedestal; those around them can treat them as exceptional and their morals something to be respected but not necessarily emulated. ${ }^{34}$

These defensive measures, among others, prevent direct attacks from achieving as much as critics hope for. (Quick et al. 2013). Kierkegaard writes, "If [a critic] becomes impatient then he makes a direct attack and accomplishes-nothing. By a direct attack he only strengthens a person in the illusion and also infuriates him. Generally speaking, there is nothing that requires as gentle a treatment as the removal of an illusion. If one in any way causes the one ensnared to be antagonized, then all is lost." ${ }^{\prime 35}$ It is generally true that people are less likely to be persuaded if they become defensive, but, as we have seen, illusions contribute to this effect by providing justifications for disregarding criticisms or inventing rejoinders. Kierkegaard notes, "It is not that Christianity is not proclaimed, but it is Christendom that has become sheer expertise in transforming it into illusion and thus evading it." ${ }^{\prime 36}$ The direct attack may seem to the critic the most forceful challenge, but it is precisely the sort of challenge those under the illusion are most adept at neutralizing.

Antagonizing rhetoric prompts the audience to frame the issue in an "us versus them" way. In response, those who feel attacked will turn to one another for confirmation that they are in the right. Polemics, Kierkegaard notes, drive people further into the logic of the crowd. ${ }^{37}$ If you say to a pastor in Christendom that he is a bad preacher, he will likely compare himself to other preachers in the process of defending himself, driving him deeper into the illusion. Even if a critic is successful and gains a few converts, they are liable to compare themselves favorably with those who have not accepted the message. This, too, is the same illusion in a different guise: rather than comparing oneself to Christ, one compares oneself to others. ${ }^{38}$ In a similar way, when a person feels judged, they will often reach for a way to excuse themselves-in Lutheran Denmark, this means turning to the "burlesque edition of the doctrine of grace." If you say to a pastor that his preaching betrays the gospel, he will likely respond, "Yes, it's true, we are all fallen creatures, but thanks be to God my salvation does not depend on the quality of my preaching." The evasions derive from and reinforce the illusions.

Kierkegaard advocates a different approach. He writes:

If one is truly to succeed in leading a person to a specific place, one must first and foremost take care to find him where he is and begin there.

This is the secret in the entire art of helping. Anyone who cannot do this is himself under a delusion if he thinks he is able to help someone else. In order to truly help someone else, I must understand more than he-but certainly first and foremost understand what he

32 Kierkegaard recorded that in Copenhagen "I am regarded as a kind of Englishman, a half-mad eccentric." Journals and Papers, 6:6254.

33 For example, if a French person objects that Americans are too sensitive, my first reaction is not to examine my own country's culture but to conclude that French culture must be very brusque.

34 As Kierkegaard notes, this is often how we treat exemplars from the past. Journals and Papers, 4:4968, 4:4973.

35 The Point of View, 43. Evans writes, "It is no good to thunder at people and affirm that they are not true Christians (thereby affirming that you are). Such a tactic only arms them by making them defensive. The correct tactic is to begin by accepting their illusion as 'good money' and subjecting it to examination. One must take people's word if they say they are Christians, and then, by humbly confessing that you personally are not a Christian, since it is so difficult, lead them to the perception of the truth." Kierkegaard's Fragments and Postscript, 52. Cf. (Kellenberger 1984).

36 The Point of View, 163.

37 The Point of View, 18-20. Cf. Works of Love, 67-68.

38 The Point of View, 147. Cf. Concluding Unscientific Postscript, 74-75, 608. 
understands. If I do not do that, then my greater understanding does not help him at all. If I nevertheless want to assert my greater understanding, then it is because I am vain or proud, then basically instead of benefitting him I really want to be admired by him. But all true helping begins with a humbling. The helper must first humble himself under the person he wants to help and thereby understand that to help is not to dominate but to serve, that to help is not to be the most dominating but the most patient, that to help is a willingness for the time being to put up with being in the wrong and not understanding what the other understands. ${ }^{39}$

On this approach, the critic not only tries to help the interlocutor, but takes care to convey this non-antagonistic relationship to her. Rather than passing judgment, the critic goes out of his or her way to listen to the interlocutor and imaginatively enter into their perspective. Kierkegaard elsewhere calls the one who does this a "ministering critic," writing "A critic is, ought to be, a ministering spirit; he is and ought to be, in the sense of ideality, the author's best friend, because he loves the author in his idea. As soon as the author gives a hint from the region in which he is or in which he wants to be, the critic immediately makes a survey, then changes his clothes according to the region and the sphere, serving $e$ concessis [on the basis of the other's premises], and from now on is the author's trusty friend." 40

The ministering critic charitably begins where the interlocutor is, but the persuasion takes the form of a guiding, a helping to find the truth. Wittgenstein summarized this well, "To convince someone of the truth, it is not enough to state it, but rather one must find the path from error to truth." (Wittgenstein 1993).

This effort to meet the interlocutor where they are must be done out of a genuine compassion for the other and a desire to help them find the truth, but that does not mean that the critic is immediately forthright about their intentions. Kierkegaard believes that in order to avoid being treated as an antagonist and to be trusted enough to minister, one may need to hide one's rhetorical goals and temporarily obscure one's own viewpoint. He talks about this in terms of "the incognito" and "deception," writing that when one is trying to remove another's delusion, "one does not begin directly with what one wishes to communicate but begins by taking the other's delusion at face value." ${ }^{41}$ The indirect communicator begins by expressing concerns and values familiar to the interlocutor, sometimes accommodating their style to the interlocutor's preferences, and works from there to broaden the interlocutor's horizons. Thus, as Kierkegaard later narrates it, his early pseudonymous writings seem like purely literary or purely philosophical books, although his goals were religious-we might even say evangelistic-from the start. ${ }^{42}$

Kierkegaard's going "incognito" as a Romantic esthete, a dutiful traditionalist, and a sagacious philosopher in his pseudonymous works is not merely an effort to make readers trust him by appearing to think like them, although that certainly is a factor. ${ }^{43}$ At a deeper level, Kierkegaard's tactic involves showing that rather than these life-views comprehending the religious and surpassing it, the religious life-view is "higher" than its evidently more enlightened competitors. Here, too, the illusions Kierkegaard is challenging - that the cosmopolitan poetic lifestyle is a liberation from drab religious conformity, that Hegelian philosophizing is superior to ordinary Christian piety, that to be

39 The Point of View, 45.

40 (Kierkegaard 1998b). Cf. Tietjen, Kierkegaard, Communication, and Virtue, 83-84.

41 The Point of View, 54. David Gouwens clarifies that by "living in esthetic categories," Kierkegaard means "living for pleasure." (Gouwens 1996).

42 "Kierkegaard's lengthy literature is frankly and unabashedly evangelical. It aims to bring his learned reader into discussion and concern about religious, and particularly Christian, matters." Paul L. Holmer, On Kierkegaard and the Truth, 193. Cf. Kierkegaard, The Point of View, 23, 90. Identifying Kierkegaard's goals as religious does not exclude the fact that he intended them to be literary and philosophical accomplishments in their own right.

43 See (Cialdini 2007) on how people tend to trust those who are like them. Cialdini cites a study which shows people tend to believe an author's writings reflect the author's true attitudes, even if they know the author was assigned to argue for a specific position (Influence, 77). This may help explain how the pseudonyms could be effective in Kierkegaard's time even though most readers knew the real author's identity. 
a trustworthy spouse and citizen is fulfilling one's religious duty-are factored into his rhetorical approach. He acts as a "spy," proving that he has an insider's understanding of each of these life-views while at the same time not finding a home in any of them. ${ }^{44}$ He writes:

The world has become all too sagacious. The person who intends to work for the religious must work undercover-otherwise he is not of much use. If someone passes himself off as religious, the world has a thousand evasions and illusions with which they protect themselves against him and get rid of him. The struggle now is no longer as it was in the old days against wild passions against which direct action is appropriate. No, Christendom has run aground in sagacity. In order to get rid of it, there must be a person who is more than a match for them in sagacity. ${ }^{45}$

In this situation, a direct proponent of Christianity will likely be interpreted as propounding a viewpoint that the interlocutors have developed beyond, be it colorless pietism, unreflective credulity, or monastic legalism. Kierkegaard first needed to demonstrate that he understood the logic of the so-called higher positions in order to make his case for a life-view that at first glance resembles a so-called lower position. Only then could he credibly expose the contradictions and limitations of the sagacious life-views of his age. ${ }^{46}$ His persuasive approach is, as Christopher Ben Simpson writes, "out-narrating" competing life-views rather than directly objecting to them. ${ }^{47}$ Kierkegaard first shows that he understands these life-views from within, that he possesses the wisdom the illusion seems to provide, before making evident the cracks and self-deceptions within the illusion and guiding readers to a deeper truth.

An analogy might be useful here. Imagine a duchess decides to host a ball. She spreads the word across the land, but the morning of the ball she falls ill and decides to cancel it. She tells a few people the celebration is off and asks them to pass the message along. That afternoon, seeing how dejected her children are that the ball is cancelled, the duchess changes her mind yet again and decides that she will host the ball after all. The baron, having heard the new plan, remarks to the count that he is looking forward to that evening's ball, to which the count replies, "Oh haven't you heard? The ball has been cancelled." The baron insists, "No, the ball will happen tonight." They will go on disputing like this until the baron is able to convey that he knows what the count knows-that the ball was cancelled-but also knows something that the count does not know—that this cancellation has been annulled and everyone will dance as originally planned.

Similarly, Kierkegaard maintains that in order to convince sagacious people, one must first convince them that one understands what they understand, and only then point them to the truth they lack. Where the baron-count analogy falls short is that the ministering critic does not simply need to indicate that they know the same information as the interlocutor. The critic must show that they can see the world through the life-view the interlocutor has, can recognize the appeal and relative coherence of this perspective. Ministering criticism requires conveying an imaginative appreciation of the interlocutor's viewpoint, not just demonstrating factual superiority over the interlocutor.

Kierkegaard believes that in some situations, the incognito-hiding one's intentions, masquerading in order to subvert suspicions-is necessary in order to get past the defenses his sagacious contemporaries have built up against the religious. ${ }^{48}$ His arguments for this are reasonable, but this

44 The Point of View, 87-89. Cf. 57-70 on the early Kierkegaard's masquerading as a witty esthete. Again, we may doubt the truth of The Point of View as an autobiography and still find much of value in it as a philosophy of communication.

45 The Point of View, 163. He adds, "The person who is to be used in this way must possess what the age prides itself on, but to its own misfortune. But he must not use his sagacity to be of assistance to a new sagacity; with the aid of sagacity, he must effect a return to simplicity." The Point of View, 163.

46 Kierkegaard's pseudonymous works thus each have an element of parody to them. On Concluding Unscientific Postscript as a philosophical parody, see (Conant 1993).

47 The Truth Is the Way, 16-17, 72-73.

48 Cf. I Corinthians 9:19-23. Kierkegaard refers to this passage in Journals and Papers, 4:3915. 
approach may seem morally dubious. Kierkegaard's descriptions-deception, being a spy, "attacks from behind"49-may give the impression that this approach is manipulative, the tricks of a con artist rather than the honesty of a Christian communicator. There may be some truth to this objection, but the ministering approach need not be carried out in a manipulative way. ${ }^{50}$

At times Kierkegaard talks about indirect communication as a strategy, and at other times he talks about it as an expression of compassion. ${ }^{51}$ Indirect communication involves patient, charitable listening to the voices of the interlocutors. Though concealing one's identity and purpose may be deceptive, the goal is not to betray someone's trust but rather to get past their initial distrust and build trust, a trust rooted in genuinely understanding what the interlocutor values, and genuinely desiring to help them hear the truth that will set them free.

\section{Not Zero-Sum, but a Corrective}

"The world is like a drunken peasant; if you help him up on one side of the horse, he falls off the other side." ${ }^{25}$ With this quotation from Martin Luther, Kierkegaard expresses his attitude toward history-including and especially his attitude toward Luther. On Kierkegaard's reading, Luther had helped Christian Europe up on one side of the horse only for Christendom to fall off the other side. Kierkegaard's discussions of Luther illustrate the second aspect of indirect communication: dialectically contextualizing one's own contribution as a corrective to the misunderstandings of one's interlocutors.

As Kierkegaard writes, every situation has its illusions, and every culture its own widely shared illusions. Oftentimes, the shared assumptions of a time period are adhered to because they were reactions to the perceived problems of previous time periods. "All development is dialectical;" Kierkegaard writes, "the 'next generation' will always need the 'opposite' as corrective." ${ }^{53}$ Cultures swing, pendulum-like, from one excess to the other. As Kierkegaard saw it, Luther's reformation challenged the excesses of European Catholicism. ${ }^{54}$ Although this was a salutary development, in Lutheran countries it also had the effect of swinging the pendulum to the opposite extreme. Kierkegaard writes:

Luther's emphasis is a corrective- but a corrective made into the normative, into the sum total, is eo ipso confusing in another generation (where that for which it was a corrective does not exist). And with every generation that goes by in this way, it must become worse, until the end result is that this corrective, which has independently established itself, produces characteristics exactly the opposite of the original. And this has been the case. Luther's corrective, when it independently is supposed to be the sum total of Christianity, produces the most refined kind of secularism and paganism. ${ }^{55}$

The significance of a statement is dependent upon the situation in which it is uttered. To proclaim the same statement in a different situation is to do a different act entirely. ${ }^{56}$ As Kierkegaard saw it, Luther's emphasis on grace was saving truth in the situation Luther was in, but the situation has changed. He writes, "Luther was confronted by the exaggerated misuse of Christ as pattern; therefore he accentuates the opposite. But Luther has long since been victorious in Protestantism and Christ

49 Christian Discourses, 162. Cf. The Point of View, 43.

50 Kierkegaard recognizes some of this moral ambiguity, writing, "When a person uses the indirect method, there is in one way or another something demonic — but not necessarily in the bad sense-about it, as, for example, with Socrates." Journals and Papers, 2:1959, cf. 1:653.

51 Pattison, Kierkegaard and the Crisis of Faith, 4-5.

52 Martin Luther, quoted in For Self-Examination, 24. The quotation can be found in Luther's Works, Vol. 54: Table Talk, trans. Theodore Tappert (Philadelphia: Fortress Press, 1967), 111.

53 Journals and Papers, 1:710.

54 "The error of the Middle Ages was in imagining that men could possibly manage to be like Christ. From this came sanctification by works and the like. Then came Luther and quite rightly emphasized Christ as gift and made the same distinction between Christ as gift and as pattern as between faith and works." Journals and Papers, 2:2503.

55 Journals and Papers, 1:711.

56 Journals and Papers, 1:678, 4:4056, 4:4059, 4:4546. 
has been completely forgotten as the pattern, and the whole thing actually has become pretense in hidden inwardness." 57 Put differently, in a situation in which the demand was overemphasized, Luther emphasized the gift as a corrective. Luther's inheritors in eighteenth-century Denmark, in turn, neglected the demand and overemphasized the gift. ${ }^{58}$ Thus the "burlesque version of the doctrine of grace" Kierkegaard saw rampant in his society was not due merely to human permissiveness, but was justified by a decontextualized appeal to Luther. ${ }^{59}$

In Kierkegaard's view, then, Lutheranism in Christendom is half-true. To the extent that Danish culture emphasizes the gift at the expense of the demand, it misconstrues the Christian gospel. ${ }^{60}$ This has implications for Kierkegaard's rhetorical approach. As he sees it, his interlocutors are neither totally ignorant nor totally wrong - for interlocutors like those, a direct approach is fitting ${ }^{61}$-but rather people who believe a half-truth but are under the impression that it is the whole truth. To write as a "corrective" is to write so one's interlocutors can hold on to the facets of truth they know, while also coming to believe and act on the facets which they are missing. This means that the critic is always agreeing with the interlocutor while at the same time criticizing the interlocutor, even if the agreement or the disagreement is temporarily concealed by the incognito.

Kierkegaard writes, "My task has been to apply a corrective to the established order, not to introduce something new that might nullify or supplant it." ${ }^{62}$ Put differently, Kierkegaard does not presuppose a zero-sum contest in which only the critic or the interlocutor knows the timelessly true. Rather, the ministering critic can help the interlocutor understand what they already believe in a different light.

It is easy to think of theological disagreements as courtroom dramas in which there are two opposing sides, only one side can be right, and each side makes points and objections that the opposing side must answer. By framing his points as a corrective, Kierkegaard seeks to get past this oppositional framework, encouraging the interlocutor to seek the truth rather than to respond to objections or defend beliefs.

Kierkegaard's corrective is thus rooted in compassion for his interlocutors, commitment to the truth more so than to his own camp, and an acknowledgment that his interlocutors are getting something - in this case, the content of Christian doctrine-correct. ${ }^{63}$ He situates his own theological intervention, not in opposition to Lutheranism, but as a corrective in keeping with the spirit of Luther himself. ${ }^{64}$

But is Kierkegaard correct in saying that nineteenth-century Danes are caught in an illusion due to a misappropriation of Luther's emphasis on grace? Would it not be more accurate to say that they are simply lazy and sinful, and that they latch onto grace disingenuously to rationalize their behavior? This is an interesting historical question, but for Kierkegaard's rhetorical purposes it does not actually matter. His account does not need to be the most accurate description; it only needs to be a plausible description. For the rest of this section, we will discuss why this is so.

57 Journals and Papers 2:2503.

58 This is not to say that one needs a balance between them. A better way to think of it is that both need to be maintained simultaneously, and the tension between them helps guide Christians into living out existence-communication. Mark C. Taylor writes that Kierkegaard sees in his contemporaries "a relaxation of the spiritual tensions essential to authentic individuality." (Taylor 2000).

59 For Self-Examination, 16.

60 "Christianity's requirement is this: your life should express works as strenuously as possible; and then one more thing is required-that you humble yourself and confess: But my being saved is nevertheless grace." For Self-Examination, 17.

61 The Point of View, 53-54.

62 For Self-Examination, 256. Thinking in terms of correctives does not entail a progressive view of intellectual development. Kierkegaard writes, "My view is certainly not that it is the essentially Christian that should be improved and perfected by new modifications-I am not that speculative. No, my view is that the essentially Christian, unchanged, at times may need by way of new modifications to secure itself against the new, the new nonsense that is in vogue." The Point of View, 131.

63 "Lutheran doctrine is excellent, is the truth." For Self-Examination, 24. Cf. Journals and Papers, 1:678.

64 Journals and Papers, 2:2518, 2:2503; For Self-Examination, 24. 
To explicitly situate one's own intervention as a corrective involves telling a story about one's interlocutors that describes why they believe and do what they believe and do. This story contextualizes the interlocutors' views and actions and provides the interlocutors with a way of making sense of themselves. As Kierkegaard writes, "It is always the explanation that makes something what it now becomes." ${ }^{\prime 65}$ If one explains one's interlocutor's motives, it offers a framework for them to enter into imaginatively. The explanation can be an invitation for them to re-integrate their lives around a new narrative. This is itself an act of persuasion, but it can also make one's further persuasive efforts more believable.

If an explanation attributes evil motives to the interlocutors, the interlocutors will be unlikely to accept it as a story about themselves. ${ }^{66}$ If, however, a story paints their beliefs and actions as the product of an understandable misjudgment-still wrong and in need of correction, but the sort of error a reasonable, well-intentioned person could make-they are more likely to integrate that story with their own self-understanding. Kierkegaard calls this a "mitigating explanation." ${ }^{67}$ This charitable interpretation invites them to understand their lives-and thus perhaps to live-in a different way. It also frames the issue in a way that makes it easier for your interlocutors to recognize the truth in the critic's corrective. Counter-intuitively, a charitable interpretation can be one of the most effective tools in a critic's toolbox, especially when the goal is to change people's minds and behavior rather than to score points in a zero-sum contest.

Consider Kierkegaard's account of why people believe the illusion of objective Christianity and why they refuse to recognize the individuated, self-involving character of Christian truth. He writes:

Christianity has been abolished by the ubiquitous relegating of personality into the background. People seem to fear that an I might be a kind of tyranny, and therefore every I might be a kind of tyranny, and therefore every I must be leveled and pushed behind some objectivity. I must not have the right to say: I believe there is a God-I must say: This is Christian doctrine and I believe it, but then this $I$ is a more universal $I$, not my personal $I$. There is doctrine, objectivity everywhere, and one is prevented everywhere from getting an impression that a person is in direct relation to God. ${ }^{68}$

In this passage, Kierkegaard offers a mitigating explanation for why Danish Christians relate to Christianity merely as a set of doctrines: as a corrective against self-centeredness, people have fled to the opposite extreme and fail to recognize that they are themselves addressed by God. Kierkegaard does not downplay the consequences of this error ("Christianity has been abolished") but the motives given for the error are such that Kierkegaard's interlocutors can more readily identify with them and admit their veracity.

By telling the story this way-while recognizing there are other plausible ways to tell the story-Kierkegaard makes it less likely for his interlocutors to get defensive, more likely for them to adopt a new self-understanding, more likely to accept correction, and more likely to keep all parties open to appropriating the gospel rather than getting wrapped up in zero-sum oppositions. This corrective approach resonates with the good news of Jesus Christ, which comes simultaneously as a challenge and a fulfillment of what is previously believed.

65 Works of Love, 291. This does not mean that an activity can be described an infinite number of ways, and Kierkegaard accepts that some wrongdoing cannot be accounted for by a mitigating explanation.

66 Pascal writes, "When we want to correct someone usefully and show him he is wrong, we must see from what point of view he is approaching the matter, for it is usually right from that point of view, and we must admit this, but show him the point of view from which it is wrong. This will please him, because he will see that he was not wrong but merely failed to see every aspect of the question." Pensées, §701. Psychological studies show that people generally think of themselves as good and react against any description that attributes simply evil motives to them. See (Aronson et al. 1999).

67 Works of Love, 289-96.

68 Journals and Papers, 4:4548. 


\section{Not an Idea to Be Considered, but a Summons to Act}

"When the 'monastery' is the deviation," Kierkegaard writes, "faith must be affirmed; when the 'professor' is the deviation, imitation must be affirmed." ${ }^{\prime 69}$ That is to say, in Luther's time, the prevailing illusion was the idea of merited grace, but the prevailing illusion in Kierkegaard's own time is that Christianity is a system of doctrines and ideas to be evaluated dispassionately, and if believed, believed in a generic way. We can call the latter "intellectualized Christianity."70 As with the other illusions we have discussed, intellectualized Christianity is more of a tendency than a self-avowed position—if asked, people might not say Christianity is chiefly a matter of intellectual assent, yet they continue to act as if it were.

As we have seen, Kierkegaard believes the needed corrective in this situation is to make people aware of the self-involving character of Christian truth. Intellectualized Christianity emphasizes the objective over the subjective and the generic over the individuated, and treats ethical and religious truths as matters of putative knowledge one can "stand outside" and evaluate at arm's length. ${ }^{71}$

Kierkegaard believes this is a misunderstanding of the grammar of ethical and the religious truth. In the "Two Lectures on Communication," he offers the following parable, "They tell a story about an army recruit who was supposed to learn to drill. The sergeant said to him: You, there, stand up straight. Recruit: 'Sure enough.' Sergeant: 'Yes, and don't talk during drill.' Recruit: 'All right, I won't do that.' Sergeant: 'No, you are not supposed to talk during drill.' Recruit: 'Yes, yes, if I just know it.'"72 In this comedic scene, the recruit makes the mistake of interpreting the sergeant's words as conveying information rather than giving commands. Intellectualized Christianity makes a similar mistake. People under this illusion treat Christianity first and foremost as a system of doctrines and neglect, postpone, or disparage the demands to die to yourself, follow Christ, love your neighbor, and depend entirely on God's grace.

In this situation, Kierkegaard has to be especially careful not to give his readers the impression that his own contribution is another idea to be considered. As David Gouwens writes, Kierkegaard's style "aims at preventing understanding unaccompanied by inner change."73 Kierkegaard takes pains to communicate in ways that impede his readers from interpreting his works as offering objective reflections on ethics and religion. He does not simply argue that people ought to move beyond objective reflection - if he did, they might simply objectively reflect on his arguments. ${ }^{74}$ It would be ironic for Kierkegaard to present his challenge as another philosophical idea—this time an "existential" one-for objective consideration.

First, Kierkegaard insists that one must not try to defend Christianity. "To defend something," he writes, "is always to disparage it." ${ }^{\prime 75}$ Kierkegaard is not saying that the truth of Christianity is so well-founded that there is no point in arguing with anyone who questions it. Rather, he is saying that to treat Christianity as a hypothesis, to weigh arguments for and against it, is to turn it into something it is not. Properly understood, Christianity demands passionate commitment of the whole self; the only responses that indicate one has understood this demand are obedience or offense. Christianity promises wholeness and redemption; the only responses that indicate one has understood this demand are faith or despair. In neither case is the objective, speculative posture of the detached thinker a reaction

69 For Self-Examination, 196. Cf. 209.

70 Kierkegaard opposed intellectualized Christianity, but as David Gouwens notes, it is misleading to call Kierkegaard anti-intellectual. Kierkegaard as a Religious Author, 51-54.

71 Journals and Papers, 4:4967.

72 Journals and Papers, 1:290. Cf. 1:273.

3 Gouwens, Kierkegaard as a Religious Author, 5.

74 Concluding Unscientific Postscript, 249-50. Cf. Journals and Papers 1:633. Cf. Holmer, Kierkegaard and the Truth, 51; Holmer, Communicating the Faith Indirectly, 14; Pattison, Kierkegaard and the Crisis of Faith, 88; Evans, Kierkegaard's Fragments and Postscript, 103-4.

75 The Sickness unto Death, 87. Cf. Christian Discourses, 162; Works of Love, 200; Concluding Unscientific Postscript, 545-46, 608; Journals and Papers 1:824, 3:3073. 
that indicates understanding. In the parable of the recruit, if the recruit had replied to the sergeant, "No, I refuse to be silent during drill!" this rejection would be closer to understanding the sergeant's command than treating it as a piece of information to store away or a theory to consider. Similarly, someone who understands the demand of Christianity and takes offense to it, or insists that they cannot meet this demand, is closer to the truth of Christianity than someone who believes in it as a set of doctrines. ${ }^{76}$

There is a danger to Kierkegaard's approach. By avoiding the temptation to defend Christianity, a Christian risks being seen as credulous, a person who believes for flimsy reasons or no reasons at all. Many apologists believe that in order to show Christianity is not a mere "leap of faith," Christians ought to develop arguments for the reasonableness of Christian belief. Kierkegaard sees this effort as a betrayal of the gospel. ${ }^{77}$ By offering reasons to the thinker who doubts the objective truth of Christianity, one implicitly confirms the picture they have of themselves as impartial judges who can withhold judgment until given sufficient reason to believe. According to Kierkegaard, this picture of the thinker-as-judge is false. The thinker is always already an existing person, imaginative and emotional, caught up in relational networks of demand and promise, forced at every moment to make decisions that reflect and shape their character. To treat a truth that involves the whole person as though it were simply a matter of cognitive assent is to diminish and distort this truth. Even if this apologetic effort brings intellectual respectability to Christianity, it comes at the cost of abolishing Christianity and contributing to an illusory picture of the human being.

Second, Kierkegaard seeks to overcome intellectualized Christianity not by showing how everything fits together in a neat, rational picture, but rather by dwelling on the paradoxes and absurdities of Christian faith. ${ }^{78}$ Most famously, in Fear and Trembling, Kierkegaard's pseudonym Johannes de Silentio reflects at length on Abraham's near-sacrifice of Isaac in Genesis 22 as a limit case for theological reflection. (Kierkegaard 1983). Abraham's actions cannot be comprehended by human reason, cannot be justified within a system of ethics, and cannot readily be squared with characterizations of a loving God. Kierkegaard insists that we should not try to rationalize away this incongruity, but dwell on it and allow it to call into question the categories we would use to evaluate it.

As we have discussed, Kierkegaard believes Christianity is not the sort of thing that could be comprehended by mere reason because Christianity makes demands on the whole existing person. He writes, "Christianity entered into the world not to be understood but to be existed in. This cannot be expressed more strongly than by the fact that Christianity itself proclaims itself to be a paradox." ${ }^{\prime 79}$ Kierkegaard does not simply exhort his readers to "exist in" Christianity, nor does he give the impression that his version of Christianity is a higher one, an existential one. Rather, he dwells on the elements of Christianity that cannot be neatly comprehended by objective reflection-the paradox of history and eternity, the paradox of the God-man, the paradox of faith as self-abasement and self-fulfillment. The goal is not to make Christianity seem irrational, but to compel readers to recognize that Christianity is more than merely rational. ${ }^{80}$ Kierkegaard's stylistic decisions, as well as his decisions on content, are made with consideration of the distinctive nature of his situation and the nature of Christian commitment.

76 Kierkegaard's pseudonym Johannes Climacus says he is not a Christian because he cannot meet the demand. See Evans, Kierkegaard's Fragments and Postscript, 52.

77 For Self-Examination, 68; Christian Discourses, 189-90; Journals and Papers 1:649; (Kierkegaard 1985).

78 Journals and Papers, 1:7, 2:1144, 2:1530, 3:3079, 3:3095.

79 Journals and Papers, 3:3084.

80 Evans writes, "The fact that this content is paradoxical in form and that it is the limit or boundary to reason should force the individual to see that the proper relation to assume toward it is not that of detached intellectual contemplation but existential commitment. The paradox should, like Kant's antimonies, serve as a 'hint' to turn the individual from speculative to more practical issues." Kierkegaard's Fragments and Postscript, 241. 


\section{Not a Position to Agree with, but an Occasion for Self-Examination}

The final component of Kierkegaard's theology of communication is a commitment to communicating so as to involve the interlocutor as an active participant. "The most interesting reading," he writes, "is one in which the reader himself is to a certain degree productive." (Kierkegaard 1987). This is especially the case when the truth one seeks to communicate needs to be subjectively appropriated, not just objectively assented to. Kierkegaard's method of indirect communication involves tactics aimed at making the reader an active participant in the reading process, with the aim of encouraging the reader to take an active part in their own upbuilding.

Kierkegaard insists that he writes "without authority." Since faith is essentially an encounter between the single individual and God, anyone who serves as a "middle term" can only get in the way. As we have discussed, Kierkegaard identifies as an illusion the practice of comparing oneself to other people-especially "the crowd" - to determine whether or not one is Christian. Properly understood, Christianity is a matter of the single individual's relation to God, even if this relation is formed and fostered in community with other people. A correlative illusion is to believe in Christian truth on another person's authority. For Kierkegaard it is impossible to take someone's word for it that you are a beloved sinner in the eyes of God; secondhand faith is a grammatical confusion. Kierkegaard's thought on this matter is paradoxical, and I will not analyze it in any detail. ${ }^{81}$ At a minimum, we can say that reading an author as an authority is more likely to distract readers from the inward reflection and holistic commitment required by Christianity than to facilitate this reflection. First, to treat someone as an authority, in this sense, is to agree with them without doing the work of examining whether what they say is true. Reading an authority is passive, whereas faith for Kierkegaard is essentially active. Second, when readers are critically engaged, they are liable to question whether or not the author is a credible authority, which can distract from the issue at hand. Finally, treating authors as authorities can lead to the formation of factions (the "I follow Paul"/"I follow Apollos" problem in the New Testament ${ }^{82}$ ) that incline readers to compare themselves to others rather than to existential self-examination.

In order to encourage readers to read his books "without authority," Kierkegaard published books under a variety of pseudonyms. Kierkegaard was not especially concerned with secrecy; many of Kierkegaard's contemporaries knew who actually wrote the pseudonymous works. As Stephen Backhouse writes, "The pseudonyms are not watertight, neither are they meant to deceive utterly and completely. Instead, pseudonymity is a mechanism by which the reader is forced to pause and consider their own relation to the text rather than to the author." (Backhouse 2016). Even if readers come to trust Kierkegaard and treat him as an authority, they cannot simply become passive readers, because the different pseudonyms express conflicting views. The many unanswered questions, counter-intuitive statements, and unresolved dialogues in Kierkegaard's writings serve the same purpose. ${ }^{83}$ To the degree that Kierkegaard is obscure, it is not because he is trying to seem intelligent or to evade criticism. He is trying to weave a spiderweb so fine it lets everything through save the single individual. Kierkegaard makes himself difficult to agree with, because the point is not to agree with him but to change your life.

Instead of trying to convince his readers to believe something, Kierkegaard first and foremost wants to persuade his readers to do something, namely, self-examination. As we have discussed, convincing them that this action is worth doing is not the same as persuading them to do it; one can intellectually

81 See his account of how one must "stand alone-by another's help" in Journals and Papers, 1:650. Cf. Journals and Papers, 1:238, 1:650, 2:1441, 4:4750; Works of Love, 274-79; Philosophical Fragments, 10; (Kierkegaard 1988). Antony Aumann gives a helpful analysis on Kierkegaard's views on authority. See Aumann, "Kierkegaard and the Need for Indirect Communication," 66-78.

82 I Corinthians 3. Cf. The Point of View, 133; Pattison, Kierkegaard and the Crisis of Faith, 27-28.

83 Journals and Papers, 4:4266. 
agree that something is worthwhile without acting on it. ${ }^{84}$ In some cases, explaining why an action is worth doing may actually make people less likely to do it. For example, say there is a movie that does not look very good from the previews, but has a twist ending that redeems it. Knowing you enjoy movies with twists, I conclude that you would really like it. I cannot simply tell you there is a twist; that would ruin it. To persuade you to watch the movie, I might need to be indirect. I may need to be temporarily deceptive and trust that you will forgive the deception after you see the ending.

When it comes to religion, the stakes are infinitely higher, but the principle is similar. People are reluctant to examine themselves, to confront their own self-deceptions, and to admit their own need for divine grace. Only after they have gone through this process can they fully recognize it as liberating and upbuilding. Kierkegaard's pseudonymous texts are, according to his own interpretation, efforts at tricking people into examining their own lives. A person needs to go through this process of reflection for themselves; they cannot simply be told the results by someone else. Given their present misunderstanding, hearing the results of the process may dissuade them from going through the process. This is deceptive, but it is deceptive only in the sense of temporarily withholding information rather than giving false information. ${ }^{85}$ It is debatable whether or not Kierkegaard's approach is manipulative, but three observations deserve mentioning: (1) since Kierkegaard's interlocutors are self-deceived and double-minded, his works aim at getting them to do something they simultaneously desire and fear. He is not tricking them to do something they wholeheartedly do not want to do, only enabling them to overcome the hurdles they have set up to the self-understanding they seek. ${ }^{86}$ (2) Hyperbolic language notwithstanding, Kierkegaard does not force his readers to do anything. There is no threat or reward, readers can always choose to close the book. It is more accurate to say that Kierkegaard creates an occasion in which people can allow themselves to be confronted by the truth. ${ }^{87}$ (3) Kierkegaard's writing is what George Pattison calls "a pedagogy of freedom." 88 His goal is paradoxically to compel readers to judge for themselves, freed from social pressure-even pressure from Kierkegaard himself-to see themselves through the eyes of God.

In addition to refraining from offering results and conclusions, Kierkegaard puts his readers to work. "For example," he writes, "it is indirect communication to place jest and earnestness together in such a way that the composite is a dialectical knot-and then to be a nobody oneself. If anyone wants to have anything to do with this kind of communication, he will have to untie the knot himself." 89 Kierkegaard sees his proximate goal as overcoming the inertia of the various dogmatisms, which cannot be done either by simply agreeing with or simply disagreeing with interlocutors' prior attitudes. The critic must present the interlocutor with a problem that the interlocutor cannot easily solve with their existing conceptual tools. Even if they go on to dismiss the author, misread the author, or abandon the question, the interlocutor is for a brief moment made to reflect on their own habits of interpreting. In Kierkegaard's terms the interlocutor is made "aware" 90 of their own categories as well as the possibility that these categories do not exhaust the phenomena. Hence, though the work of untying a dialectical knot is not the same as the work of coming to faith, it can prepare readers to reevaluate their own life-views.

84 One example: if asked, I would say that I believe local politics are important and people should be more involved in them. I am not in any way involved in local politics, and act as if it were insignificant. This belief, if we want to call it a belief, is mere intellectual agreement without existential commitment.

85 Kierkegaard calls it "truth's way of deceiving." The Point of View, 58. Cf. Journals and Papers, 1:649.

86 Katherine M. Ramsland writes, "The communicator wants simply to display possibilities to the recipients so that they will regard them in some relation to themselves. Recipients are not so much manipulated as disarmed of their resistance and defense so that they can be offered what is their own." (Ramsland and Kierkegaard 1989).

87 Cf. Evans, Kierkegaard's Fragments and Postscript, 102-7.

88 Pattison, Kierkegaard and the Crisis of Faith, 5.

89 Practice in Christianity, 133. Cf. Concluding Unscientific Postscript, 298, "Thus it is left to the reader to put it all together by himself ..."

90 The Point of View, 50-53. 
Finally, Kierkegaard compares his indirect communication with Socrates's "maieutic" approach. Socrates likens himself to a midwife, saying that rather than making his own conclusions, he merely brings forth the ideas that his interlocutors already believed. (Plato 2014). As we have discussed, Kierkegaard does not want his readers to passively accept his conclusions, but to embark on a journey of self-examination on which they come face-to-face with the demand, the fall, the gift, and the ongoing task of existence-communication. Even when he cannot guide them through this journey, he encourages them to become aware, to take an active interest in their own existence. Kierkegaard does not want his readers to receive, but to react. Reading Kierkegaard's books, more so than other books, is a participatory activity. Readers are not presented with a completed dish to consume, as it were, but the fragments of a recipe they need to piece together, making their own contributions to fill in the gaps.

In Kierkegaard's view, the reader's effort and the reader's contributions are integral to the appropriation of the message. It is true, as Pascal writes, that "We are usually convinced more easily by reasons we have found ourselves than by those which have occurred to others." ${ }^{\prime 91}$ But on a deeper level, for Kierkegaard the truth of Christianity cannot be believed any other way. In order for the Christian gospel to be individuated, to be true for me, I need to recognize it as such.

Kierkegaard's point here is difficult to summarize, but a distinction from William James is helpful. James distinguished between the "I" and the "me," with the "I" being the subjective self and the "me" being the objective self. ${ }^{92}$ Other people can tell me facts about myself, about "me," and I can believe these facts mediated through their interpretations. By contrast, the "I" is my ego as I act with it, my own first-person perspective. The "me" includes the parts of myself I identify with, the " $\mathrm{I}$ " is the part of the self that does the identifying.

For Kierkegaard, Christian confessions like "I am a sinner," "I stand in need of divine grace," and "I am beloved" need to be confessed by the "I," not just admitted as true statements about "me." Through maieutic writing, Kierkegaard encourages readers not merely to acquiesce to descriptions of themselves, but to actively assert their identity and in the process to discover deeper truths about themselves. To borrow a term from Kevin Hector, Christian faith requires mineness, and the maieutic is Kierkegaard's method of facilitating this in his readers. (Hector 2015). In Kierkegaard's theology of communication, the essentially Christian confession is an active, independent self-discovery, and to directly report to someone their status before God is to get in the way of this confession.

The truth about one's self, and the passion with which one reaches out to God and loves one's neighbor, cannot be given from one person to another. Rather, these exist within each person as glowing embers. A critic who wants to help stoke these embers into a flame can at most help create the conditions in which what is already within the interlocutor can be more fully realized and expressed. ${ }^{93}$ The essential truths, then, cannot be communicated directly, but can be maieutically brought out through indirect communication, which makes the reader active, sets the reader free, and encourages the reader to come face to face with the living God.

Funding: This research received no additional funding.

Conflicts of Interest: The author declares no conflict of interest.

91 Pascal, Pensées \$737. Kierkegaard makes a similar point in Journals and Papers, 1:629. This argument is found implicitly in Aristotle's account of enthymemes in Rhetoric (Mineola, NY: Dover, 2004). More recent research in the psychology of persuasion supports this notion. See Anthony Greenwald, "Cognitive Learning, Cognitive Response to Persuasion, and Attitude Change" in Psychological Foundations of Attitudes, eds. Anthony Greenwald, Timothy Brock, and Thomas Ostrom (New York: Academic Press, 1968), 147-70.

92 (James 1950). James's discussion of the self is much more complex than the rough outline here, and the distinction has been expanded in subsequent theorizing about the self. Cf. (Ashmore and Jussim 1997).

93 This is what Kierkegaard means by "upbuilding" as opposed to "teaching." See Works of Love, 209-24, 274-80. Cf. Journals and Papers, 1:508, 1:641, 2:1251. 


\section{References}

Aronson, Joshua, Geoffrey Cohen, and Paul Nail. 1999. Self-Affirmation Theory: An Update and Appraisal. In Cognitive Dissonance. Edited by Eddie Harmon-Jones and Judson Mills. Washington: American Psychological Association.

Ashmore, Richard, and Lee Jussim, eds. 1997. Self and Identity. Oxford: Oxford University Press.

Augustine, St. 1997. On Christian Teaching. Translated by Roger P. Green. Oxford: Oxford University Press.

Aumann, Antony. 2008. Kierkegaard and the Need for Indirect Communication. Ph.D. Dissertation, Indiana University, Bloomington, IN, USA; pp. 153-54.

Backhouse, Stephen. 2016. Kierkegaard: A Single Life. Grand Rapids: Zondervan, p. 115.

Cialdini, Robert. 2007. Influence: The Psychology of Persuasion. New York: HarperCollins, pp. 140-42.

Compier, Don H. 1999. What Is Rhetorical Theology? Harrisburg: Trinity Press International.

Conant, James. 1993. Kierkegaard, Wittgenstein, and Nonsense. In Pursuits of Reason: Essays in Honor of Stanley Cavell. Edited by Ted Cohen, Paul Guyer and Hilary Putnam. Lubbock: Texas Tech University Press, pp. 195-224.

Garff, Joakim. 2005. Søren Kierkegaard. Princeton: Princeton University Press, p. 562.

Gouwens, David J. 1996. Kierkegaard as Religious Thinker. Cambridge: Cambridge University Press, pp. 15-16.

Hector, Kevin W. 2015. The Theological Project of Modernism: Faith and the Conditions of Mineness. Oxford: Oxford University Press.

Holmer, Paul L. 2012a. Communicating the Faith Indirectly. Eugene: Cascade Books, p. 36.

Holmer, Paul. 2012b. On Kierkegaard and the Truth. Eugene: Cascade Books, p. 240.

James, William. 1950. The Principles of Psychology. New York: Dover, pp. 291-401.

Jost, Walter. 1994. On concealment and deception in rhetoric: Newman and Kierkegaard. Rhetoric Society Quarterly 24: 51-74. [CrossRef]

Kellenberger, James. 1984. Indirect Communication, and Religious Truth. International Journal for Philosophy of Religion 16: 158. [CrossRef]

Kierkegaard, Søren. 1980. The Sickness unto Death. Translated by Howard Hong, and Edna Hong. Princeton: Princeton, p. 87.

Kierkegaard, Søren. 1983. Fear and Trembling. Translated by Howard Hong, and Edna Hong. Princeton: Princeton.

Kierkegaard, Søren. 1985. Philosophical Fragments/Johannes Climacus. Translated by Howard Hong, and Edna Hong. Princeton: Princeton University Press, p. 170.

Kierkegaard, Søren. 1987. Either/Or, Part II. Translated by Howard Hong, and Edna Hong. Princeton: Princeton University Press, p. 110.

Kierkegaard, Søren. 1988. Stages on Life's Way. Translated by Howard Hong, and Edna Hong. Princeton: Princeton University Press, p. 344.

Kierkegaard, Søren. 1991. Practice in Christianity. Translated by Howard Hong, and Edna Hong. Princeton: Princeton University Press, p. 144.

Kierkegaard, Søren. 1992. Concluding Unscientific Postscript to Philosophical Fragments. Translated by Howard Hong, and Edna Hong. Princeton: Princeton University Press, p. 467.

Kierkegaard, Søren. 1995. Works of Love. Translated by Howard Hong, and Edna Hong. Princeton: Princeton University Press, p. 119.

Kierkegaard, Søren. 1997. Christian Discourses. Translated by Howard Hong, and Edna Hong. Princeton: Princeton University Press, p. 165.

Kierkegaard, Søren. 1998a. The Point of View. Translated by Howard Hong, and Edna Hong. Princeton: Princeton University Press, p. 23.

Kierkegaard, Søren. 1998b. The Book on Adler. Translated by Howard Hong, and Edna Hong. Princeton: Princeton University Press, pp. 18, 31.

Kierkegaard, Søren. 1999. Søren Kierkegaard's Journals and Papers, 2nd ed. Translated by Howard Hong, and Edna Hong. Bloomington: Indiana University Press, vol. 1, p. 627.

Peters, John Durham. 2012. Speaking into the Air: A History of the Idea of Communication. Chicago: University of Chicago Press, p. 128.

Plato. 2014. Theaetetus. Translated by John McDowell. Oxford: Oxford University Press. 
Quick, Brian L., Lijiang Shen, and James Price Dillard. 2013. Reactance Theory and Persuasion. In The SAGE Handbook of Persuasion. Edited by James Price Dillard and Lijiang Shen. Thousand Oaks: SAGE Publications, pp. 167-83.

Ramsland, Katherine M., and Søren Kierkegaard. 1989. Engaging the Immediate: Applying Kierkegaard's Concept of Indirect Communication to the Practice of Psychotherapy. Lewisburg: Bucknell University Press, p. 84.

Roberts, Kyle. 2019. Kierkegaard on Communication: Refusing to 'Piddle'. In TET Clark Companion to the Theology of Kierkegaard. Edited by Aaron Edwards and David Gouwens. London: T\&T Clark.

Taylor, Mark C. 2000. Journeys to Selfhood: Hegel and Kierkegaard. New York: Fordham University Press, p. 53.

Tietjen, Mark. 2013. Kierkegaard, Communication, and Virtue: Authorship as Edification. Bloomington: Indiana University Press, p. 34.

Toulmin, Stephen, and Allan Janik. 1973. Wittgenstein's Vienna. New York: Simon and Schuster, p. 160.

Wittgenstein, Ludwig. 1993. Philosophical Occasions 1912-1951. Edited by James Klagge and Alfred Nordmann. Indianapolis: Hackett, p. 119.

(C) 2020 by the author. Licensee MDPI, Basel, Switzerland. This article is an open access article distributed under the terms and conditions of the Creative Commons Attribution (CC BY) license (http://creativecommons.org/licenses/by/4.0/). 